\title{
EVALUATION OF IRON CONCENTRATION OF FIVE NIGERIAN SHRUBS FOR THEIR PROSPECTIVE USE IN THE THERAPY OF IRON DEFICIENCY ANEMIA (IDA)
}

\author{
Obika, \\ Ogochukwu \\ Immaculate $^{1}$ \\ Ochekwu, Edache \\ Bernard $^{2+}$
}

\author{
${ }^{1,2}$ Department of Plant Science and Biotechnology, University of Port \\ Harcourt, Nigeria. \\ ${ }^{2}$ Email:obika.immaculate@gmail.com Tel: +2348060982961 \\ 'Email:edacheb@gmail.com Tel: +2347034501934
}

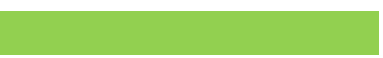

\begin{abstract}
Medicinal herbs are commonly being used in the treatment of anemia traditionally and Jatropha tanjorensis Ellis \& Saroja, Vernonia amygdalina Delile, Manihot esculenta Crantz, Megaskepasma erythrochlamys Lindau, Solanum macrocarpon L. are local shrubs mostly employed. This study aims to analyze the prospective use of some local shrubs in the therapy of Iron Deficiency Anemia. The proximate composition analysis and the iron content in leaves of the shrubs were determined following the methods of the association of official analytical chemists (A.O.A.C). The results obtained for iron concentration show Jatropha tanjorensis $3.11 \mathrm{~g} / \mathrm{kg}$, Vernonia amygdalina $1.64 \mathrm{~g} / \mathrm{kg}$, Manihot esculenta $0.57 \mathrm{~g} / \mathrm{kg}$, Megaskepasma erythrochlamys $1.23 \mathrm{~g} / \mathrm{kg}$, and Solanum macrocarpon $2.75 \mathrm{~g} / \mathrm{kg}$. The range of proximate composition as; protein had Megaskepasma erythrochlamys as the lowest value $3.97 \%$ and Vernonia amygdalina as the highest value $50.64 \%$, fat \& oil content showed Jatropha tanjorensis with the highest value $1.04 \%$ and Megaskepasma erythrochlamys having the lowest value $29.77 \%$, Fiber content showed Vernonia amygdalina has the highest value $1.81 \%$ and Solanum macrocarpon has the lowest $12.08 \%$, the carbohydrate content showed Megaskepasma erythrochlamys as the lowest value $2.39 \%$ and Manihot esculenta as the highest value $21.02 \%$, and the moisture content showed Manihot esculenta has the lowest value 9.98\% and Megaskepasma erythrochlamys has the highest value $83.25 \%$. All five plants have great potential for the treatment of iron deficiency anemia.
\end{abstract}

Article History

Received: 4 June 2021

Revised: 6 July 2021

Accepted: 12 August 2021

Published: 8 September 2021

\section{Keywords}

Anemia

Iron deficiency

Iron content

Proximate analysis

Medicinal plants

Vernonia amygdalina

Manihot esculenta

Jatropha tanjorensis

Megaskepasma erythrochlamys

Solanum macrocarpon.

Contribution/Originality: This study contributes to the existing literature of plants as remedy to Anemia by using spectrophotometer to reveal the amount of iron content and hence, the efficiency of the plants in combatting Iron Deficiency Anemia.

\section{INTRODUCTION}

In addition to the major economic uses of plants as food, shelter, and clothing, specific plants make terrific natural medicines [1]. Plants restore, rehabilitate, resuscitate and revitalize just as they are nourishing, and following what Hippocrates the Father of Medicine said "Let Food be your Medicine and Medicine be your Food", a green leaf soup or juice is a supplement as much as it is food [2]. The kingdom Plantae contributed immensely to human health when there were no pharmaceutically formulated medicines, and when no concept of surgery existed [3]. Medicinal plants are widely used and constitute the main source of new pharmaceuticals and healthcare products, in industrialized countries these plants have been used in the development of new drugs, founding the basis of healthcare throughout the world since ancient times and have considerable importance in international 
trade [4]. Medicinal plants are divine gifts to mankind from Mother Nature's abundance in her plant kingdom's green remedies for cure from ailments and combating death from disease. More than 50,000 species of higher plants all have been used medicinally and about 100 plant species have contributed significantly to the development of modern drugs [5]. Medicinal plants are holistic approach with little or no adverse effects on the body [6]. Medicinal plants are now being reaccepted within the last few decades, and witnessing a shift in focus back to the forgotten traditional natural medicine. In the Western and developed world, people are returning to herbal drugs [7], and as more people learn about the nutritional and medicinal value of plants, they will improve their attitude towards herbs and increase their consumption of plants resulting in improved health.

Table-1. The recommended daily allowance (RDA) of iron by age and gender group.

\begin{tabular}{|c|c|c|c|c|c|c|c|c|c|c|}
\hline \multirow[b]{2}{*}{ @ָ } & \multirow[b]{2}{*}{ 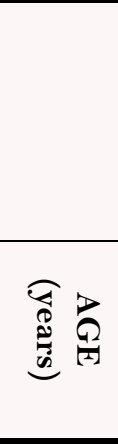 } & \multirow[b]{2}{*}{ 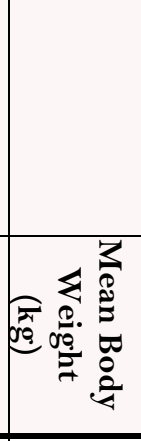 } & \multirow[b]{2}{*}{$\begin{array}{l}\text { Required } \\
\text { Iron } \\
\text { Intake for } \\
\text { Growth } \\
\text { (mg/day) }\end{array}$} & \multicolumn{2}{|c|}{$\begin{array}{c}\text { Median Iron } \\
\text { Losses } \\
\text { (mg/day) }\end{array}$} & \multirow[b]{2}{*}{ 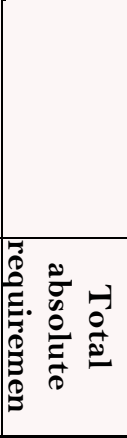 } & \multicolumn{4}{|c|}{$\begin{array}{c}\text { Recommended iron intakes to } \\
\text { cover requirements of } \\
\text { different bioavailability } \\
\text { (mean + } \mathrm{SD})(\mathrm{mg} / \mathrm{day}) . \\
\text { Level of dietary iron } \\
\text { bioavailability } \%\end{array}$} \\
\hline & & & & 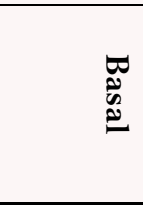 & 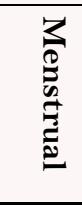 & & 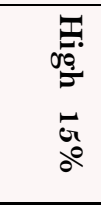 & 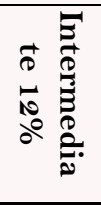 & $\begin{array}{l}5 \\
\vdots \\
z \\
0 \\
0 \\
d\end{array}$ & or $\frac{\overbrace{2}^{\frac{2}{2}}}{\frac{\pi}{4}}$ \\
\hline Children & $\begin{array}{c}0.5-1 \\
1-3 \\
4-6 \\
7-10 \\
\end{array}$ & $\begin{array}{c}9.0 \\
13.3 \\
19.2 \\
28.1 \\
\end{array}$ & $\begin{array}{l}0.55 \\
0.27 \\
0.23 \\
0.32 \\
\end{array}$ & $\begin{array}{l}0.17 \\
0.19 \\
0.27 \\
0.39 \\
\end{array}$ & & $\begin{array}{l}0.72 \\
0.46 \\
0.50 \\
0.71 \\
\end{array}$ & $\begin{array}{l}6.2^{b} \\
3.9 \\
4.2 \\
5.9 \\
\end{array}$ & $\begin{array}{l}7.7^{b} \\
4.8 \\
5.3 \\
7.4 \\
\end{array}$ & $\begin{array}{l}9.3^{b} \\
5.8 \\
6.3 \\
8.9 \\
\end{array}$ & $\begin{array}{l}18.6^{b} \\
11.6 \\
12.6 \\
17.8 \\
\end{array}$ \\
\hline Males & $\begin{array}{c}11- \\
14 \\
15- \\
17 \\
18+ \\
\end{array}$ & $\begin{array}{l}45.0 \\
64.4 \\
75.0\end{array}$ & $\begin{array}{l}0.55 \\
0.60\end{array}$ & $\begin{array}{l}0.62 \\
0.90 \\
1.05\end{array}$ & & $\begin{array}{l}1.17 \\
1.50 \\
1.05\end{array}$ & $\begin{array}{l}9.7 \\
12.5 \\
9.1\end{array}$ & $\begin{array}{l}12.2 \\
15.7 \\
11.4\end{array}$ & $\begin{array}{l}14.6 \\
18.8 \\
13.7\end{array}$ & $\begin{array}{l}29.2 \\
37.6 \\
27.4\end{array}$ \\
\hline Females & $\begin{array}{c}11- \\
14^{\mathrm{c}} \\
11- \\
14 \\
15- \\
17 \\
18+\end{array}$ & $\begin{array}{l}46.1 \\
46.1 \\
56.4 \\
62.0\end{array}$ & $\begin{array}{l}0.55 \\
0.55 \\
0.35\end{array}$ & $\begin{array}{l}0.65 \\
0.65 \\
0.79 \\
0.87\end{array}$ & $\begin{array}{l}0.48 \\
0.48 \\
0.48\end{array}$ & $\begin{array}{l}1.20 \\
1.68 \\
1.62 \\
1.46\end{array}$ & $\begin{array}{c}9.3 \\
21.8 \\
20.7 \\
19.6\end{array}$ & $\begin{array}{l}11.7 \\
27.7 \\
25.8 \\
24.5\end{array}$ & $\begin{array}{l}14.0 \\
32.7 \\
31.0 \\
29.4\end{array}$ & $\begin{array}{l}28.0 \\
65.4 \\
62.0 \\
58.8\end{array}$ \\
\hline $\begin{array}{c}\text { Post- } \\
\text { menopause }\end{array}$ & & 62.0 & & 0.87 & & 0.87 & 7.5 & 9.4 & 11.3 & 22.6 \\
\hline Lactating & & 62.0 & & 1.15 & & 1.15 & 10.0 & 12.5 & 15.0 & 30.0 \\
\hline $\begin{array}{l}\text { Note: } \\
\text { Includes; require } \\
\text { Bioavailability of } \\
\text { Non-menstruatin } \\
\text { Source: } \mathrm{WHO} / \mathrm{U}\end{array}$ & $\begin{array}{l}\text { for gro } \\
\text { ary iron }\end{array}$ & $\begin{array}{l}\text { basal losse } \\
\text { ing this per } \\
\text { 3]. }\end{array}$ & $\begin{array}{l}\text { in female, men } \\
\text { iries greatly. }\end{array}$ & osses. & & & & & & \\
\hline
\end{tabular}

Iron is extremely vital in maintaining several functions of the body which include, the production of an oxygencarrying molecule known as hemoglobin [8]. Iron deficiency is defined as a condition within which there is a prominent lack of functional iron stores and there are notable signs of a compromised supply of iron to tissues, as well as the erythron [8]. Iron deficiency is a very urgent global problem and it is estimated that Iron deficiency affects than half of the global population, particularly in developing countries [9]. The more severe stages of iron deficiency are associated with anemia; Iron Deficiency Anemia (IDA) is the most common type of anemia. While the condition may be common, it is possible to experience the symptoms of iron deficiency anemia for years without ever knowing the cause due to how mild or its similarity with other conditions like exhaustion [10]. The risk population of iron deficiency anemia (IDA) includes; Infants, children, adolescents, women of childbearing age, pregnant women, people with certain medical and surgical conditions, blood donors, and elderly people [10, 11]. 
The bioavailability of iron from plants is estimated to be low due to the presence of phytic acid and polyphenols thus, the belief that plant-based diet might lead to the development of iron deficiency anemia, however, surveys in vegetarians have shown that iron deficiency anemia is not more common in them than it is in the general population, albeit vegetarians tend to have lower iron stores, and the adequate iron status of many vegetarians may be owing to the fact that commonly eaten plants are superior compared to animal-derived foods as they are high in iron along with ascorbic acid and citrate which facilitates iron absorption [12].

The high concentration of Iron in vegetables may increase the nutritional health of the people in disadvantaged areas [14]. Thus, this study attempts to analyze the prospective use of some local shrubs in the therapy of Iron Deficiency Anemia (IDA) via Iron concentration and proximate analysis. The shrubs chosen for this study include; Vernonia amygdalina Delile commonly called bitter leaf, Manihot esculenta Crantz commonly called cassava, Jatropha tanjorensis Ellis \& Saroja commonly called hospital-too-far or catholic vegetable, Megaskepasma erythrochlamys Lindau commonly called red Justicia or red cloak, Solanum macrocarpon L. commonly called local garden egg or African eggplant.

\section{METHODOLOGY}

\subsection{Materials}

Jatropha tanjorensis, Vernonia amygdalina, Manihot esculenta, Megaskepasma erythrochlamys, Solanum macrocarpon, Crucibles, soxhlet extractor, volumetric flask, oven, desiccator, Brucine reagent, sulphuric acid, distilled water, nhexane, Buchner funnel, $\mathrm{NaOH}$, petroleum ether, furnace, perchloric acid, nitric acid, Atomic absorption spectrophotometer (AAS).

\subsection{Plant Material}

Leaves of the Solanum macrocarpon were purchased from Oyigbo ultra-modern market, while the rest were harvested fresh from a farm in Oyigbo, rivers state. The leaves were diced and a portion of the fresh samples was taken and used for moisture content determination, while the rest samples were dried, pulverized, and used for the determination of crude protein, lipid, fiber, ash content, carbohydrate, and Iron content. The leaves were assayed and analyzed in triplicate

\subsection{Proximate Analysis}

The standard procedure as outlined in Official Methods of Analysis of the AOAC was employed for the determination of the percentage proximate compositions. Nitrogen was determined by the micro-kjeldahl method and the percentage of nitrogen was converted to crude protein by multiplying by 6.25, and Carbohydrate was determined by difference [15].

\subsubsection{Moisture Content:}

$2 \mathrm{~g}$ of the fresh plant materials were placed in the crucible and heated at $105^{\circ} \mathrm{C}$ until a constant weight was attained. The moisture content was calculated as the weight lost by the original plant sample and expressed as percentage moisture content.

\subsubsection{Crude Protein Content}

The crude protein was calculated by the Kjeldahl technique. $0.5 \mathrm{~g}$ of the powdery form of the plant materials was digested with $5 \mathrm{ml}$ of concentrated sulphuric acid in the presence of Kjeldahl catalyst. The nitrogen from the protein in the sample was converted to ammonium sulphate that reacted with $2.5 \mathrm{ml}$ of $2.5 \%$ Brucine reagent, $5 \mathrm{ml}$ of $98 \%$ sulphuric acid to present a colored derivative and the absorbance was read at $470 \mathrm{~nm}$. The value of the crude protein was gotten by multiplying the calculated percentage nitrogen by 6.25. 


\subsubsection{Crude Lipid Content}

The Soxhlet extraction method was used to perform this valuation. $10 \mathrm{~g}$ of the powdery form of the plant materials were weighed and put in a thimble and was defatted using $200 \mathrm{ml}$ of $\mathrm{n}$-hexane. After the solvent evaporation, the crude lipid was calculated as the percentage of the weight of extracted fat against the weight of the sample

\subsubsection{Crude Fiber Content}

The method of AOAC [15] was followed to determine the value of crude fiber. $5 \mathrm{~g}$ of the powdered plant materials were heated for $30 \mathrm{~min}$ in $200 \mathrm{ml}$ of $1.25 \% \mathrm{H} 2 \mathrm{SO} 4$ and filtered with a Buchner funnel. The residue was washed thoroughly with distilled water until it was acid free, it was then boiled in $200 \mathrm{ml}$ of $1.25 \% \mathrm{NaOH}$ for 30 min and filtered. The residue was again washed with distilled water several times until it was alkaline free. It was then rinsed once with $10 \% \mathrm{HCl}$ and twice with ethanol and finally rinsed with petroleum ether three times. The residue was put in a crucible and dried at $1050 \mathrm{C}$ in an oven overnight. After cooling in a desiccator, it was ignited in a muffle furnace at $5500 \mathrm{C}$ for 90 minutes to obtain the weight of the ash.

\subsubsection{Ash Content}

This was done using the method of A.O.A.C. $2 \mathrm{~g}$ of the pulverized plant materials each was placed in a crucible and ignited in a muffle furnace at $550{ }^{\circ} \mathrm{C}$ for 6hours. It was then cooled in a desiccator and weighed at room temperature to get the weight of the ash. The total ash content is calculated as the percentage of inorganic residue remaining after ashing the organic matter.

\subsubsection{Carbohydrate Content}

The carbohydrate content was calculated by subtracting from 100 the sum of moisture, protein, lipid, fiber, and ash contents percentage compositions.

\subsection{Mineral Analysis \\ 2.4.1. Iron Content}

The mineral assay was performed after wet ashing the sample. About $2.5 \mathrm{~g}$ of powdered plant materials was accurately weighed and ashed at $550^{\circ} \mathrm{C}$ overnight. The resulting ash was dissolved in $25 \mathrm{ml}$ of concentrated nitric acid and heated for $40 \mathrm{~min}$, after which it was allowed to cool and $10 \mathrm{ml}$ of perchloric acid was carefully added and then heated again until the fume appeared. $50 \mathrm{ml}$ of deionized water was added to the sample after being cooled. The solution was then transferred into a volumetric flask $(250 \mathrm{ml})$ and the volume was adjusted. The absorbance of the solution was taken using the Atomic absorption spectrophotometer (AAS).

\section{RESULT}

The results for the proximate composition of the 5 shrub samples are presented in Table 2 , the protein, fat \& oil (lipid), ash, fiber, carbohydrate, and moisture contents were analyzed.

The protein content showed that Jatropha tanjorensis has a concentration of $41.65 \%$, Vernonia amygdalina has a concentration of 50.64\%, Manihot esculenta has a concentration of $23.39 \%$, Megaskepasma erythrochlamys has a concentration of $3.97 \%$, and Solanum macrocarpon has a concentration of $7.37 \%$. Fat \& oil content showed that Jatropha tanjorensis has a concentration of $29.77 \%$, Vernonia amygdalina has a concentration of 9.05\%, Manihot esculenta has a concentration of 4.09\%, Megaskepasma erythrochlamys has a concentration of 1.04\%, and Solanum macrocarpon has a concentration of $1.65 \%$. The ash content showed that Jatropha tanjorensis has a concentration of $4.71 \%$, Vernonia amygdalina has a concentration of $9.56 \%$, Manihot esculenta has a concentration of $9.03 \%$, Megaskepasma erythrochlamys has a concentration of $4.80 \%$, and Solanum macrocarpon has a concentration of $1.96 \%$. 
Fiber content showed that Jatropha tanjorensis has a concentration of $4.46 \%$, Vernonia amygdalina has a concentration of $12.08 \%$, Manihot esculenta has a concentration of 10.63\%, Megaskepasma erythrochlamys has a concentration of $4.55 \%$, and Solanum macrocarpon has a concentration of $1.81 \%$. The carbohydrate value showed that Jatropha tanjorensis has a concentration of $9.43 \%$, Vernonia amygdalina has a concentration of $8.65 \%$, Manihot esculenta has a concentration of $21.02 \%$, Megaskepasma erythrochlamys has a concentration of $2.39 \%$, and Solanum macrocarpon has a concentration of $11.77 \%$. The moisture content showed that Jatropha tanjorensis has a concentration of $9.98 \%$, Vernonia amygdalina has a concentration of $10.02 \%$, Manihot esculenta has a concentration of 31.84\%, Megaskepasma erythrochlamys has a concentration of $83.25 \%$, and Solanum macrocarpon has a concentration of $75.44 \%$.

Table-2. Percentage proximate composition of the leaves of the five shrub samples.

\begin{tabular}{|c|c|c|c|c|c|c|}
\hline $\begin{array}{c}\text { Nutrient } \Rightarrow \\
\text { Plant } \\
\Downarrow\end{array}$ & ê & جٍ & $\stackrel{2}{0} \frac{b}{\sigma}$ & ْ & 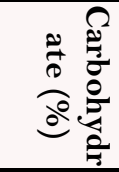 & Ð0 \\
\hline Jatropha tanjorensis & 41.65 & 29.77 & 4.71 & 4.46 & 9.43 & 9.98 \\
\hline Vernonia amygdalina & 50.64 & 9.05 & 9.56 & 12.08 & 8.65 & 10.02 \\
\hline Manihot esculenta & 23.39 & 4.09 & 9.03 & 10.63 & 21.02 & 31.84 \\
\hline M. erythrochlamys & 3.97 & 1.04 & 4.80 & 4.55 & 2.39 & 83.25 \\
\hline Solanum macrocarpon & 7.37 & 1.65 & 1.96 & 1.81 & 11.77 & 75.44 \\
\hline
\end{tabular}

Table 3 shows the iron concentration in $\mathrm{mg} / \mathrm{kg}$ in the shrubs. Jatropha tanjorensis has a concentration of $3.11 \mathrm{~g} / \mathrm{kg}$, Vernonia amygdalina has a concentration of $1.64 \mathrm{~g} / \mathrm{kg}$, Manihot esculenta has a concentration of $0.57 \mathrm{~g} / \mathrm{kg}$, Megaskepasma erythrochlamys has a concentration of $1.23 \mathrm{~g} / \mathrm{kg}$, and Solanum macrocarpon has a concentration of $2.75 \mathrm{~g} / \mathrm{kg}$.

Table-3. Iron concentration of leaves of shrub samples.

\begin{tabular}{l|c}
\hline Plant & Concentration $\mathbf{g} / \mathbf{k g}$ \\
\hline Jatropha tanjorensis & 3.11 \\
\hline Vernonia amygdalina & 1.64 \\
\hline Manihot esculenta & 0.57 \\
\hline M. erythrochlamys & 1.23 \\
\hline Solanum macrocarpon & 2.75 \\
\hline
\end{tabular}

\section{DISCUSSION}

From the result of the proximate analysis, it can be deduced that the leaves of the shrubs have the potential to be used as food because of their content in protein, carbohydrate, lipid, fiber, and water. The high moisture content and low lipid content of all the leaves except Jatropha tanjorensis agree to the general inference that leafy vegetables are high in water but low in lipids, thereby advantageous as food for health. Jatropha tanjorensis, Vernonia amygdalina, and Manihot esculenta are good sources of protein. Megaskepasma erythrochlamys and Solanum macrocarpon have higher carbohydrate content which may result in higher energy, albeit leafy vegetables are not considered important sources of carbohydrate. The fiber content in the leave samples is of beneficial effect as well [16]. The high moisture content of Megaskepasma erythrochlamys as compared to its content of other macronutrients provides validation to the local use as an infusion or juice and not as a vegetable.

From the iron concentration of these plants, it can be seen that these plants can be used as an iron source or supplement and the iron concentration is high compared to the reported value of Telfaria occidentalis which has an iron content of $0.16 \mathrm{~g} / \mathrm{kg}$ and has been reported to have anti-anemic properties [16]. With regards to the bioavailability of iron in certain diets as stipulated by WHO in 2001 in Table 1, the concentrations of iron in the shrubs can be said to be adequate if they are to be used in the treatment, therapy, or management of Iron Deficiency 
Anemia given that the bioavailability of the mineral is calculated in the regimen to be administered so that the adequate amounts are taken up by the anemic patient. Anemia having a high prevalence with iron deficiency being the most frequent form of anemia needs to be checked. Poverty is one of the reasons for the prevalence of IDA in Nigeria and these shrubs are affordable and abundant in nature for IDA therapy. Although the prevention of IDA is important it is also dangerous to have an iron overload, therefore, the proper dosage of use for these plants are required.

\section{CONCLUSION}

Jatropha tanjorensis, Vernonia amygdalina, Manihot esculenta, Megaskepasma erythrochlamys, Solanum macrocarpon can all be used in the therapy of iron deficiency anemia (IDA) according to the bioavailability level of iron as recommended by WHO in 2001, given that scientific regulations and policies are brought into play so that dosage and administration can be within acceptable ranges.

Funding: This study received no specific financial support.

Competing Interests: The authors declare that they have no competing interests.

Acknowledgement: Both authors contributed equally to the conception and design of the study.

\section{REFERENCES}

[1] I. E. M. and E. F. O., "Commonly used medicinal plants in the management of sickle cell anaemia and diabetes mellitus by the local people," International Journal of Plant Breeding and Crop Science, vol. 2, pp. 14-19, 2013.

[2] M. Idu, The plant called medicine",104th inaugural lecture series of the university of benin, 3rd ed. Benin City Nigeria, Calameo: The Inaugural Lecture Series of the Department of Plant Biology and Biotechnology, 2009.

[3] O. C. Nwachukwu, A. J. Aronu, and O. Adebayo, "Influence of seed maturity on germination rate (Dennettia tripetala) pepper fruit," Journal of Enviromental Issues \& Agriculture in Developing, vol. 2, pp. 87-91, 2010.

[4] E. B. Ochekwu, C. Ekeke, P. O. Nwadiaro, and S. Christopher, "Phytochemical evaluation of leaves of some medicinal plants from parts of Niger Delta," IOSR Journal of Pharmacy and Biological Sciences, vol. 10, pp. 26-31, 2015.

[5] S. Pan, S. Zhou, S. Gao, Z. Yu, S. Zhang, M. Tang, J. Sun, D. Ma, Y. Han, W. Fong, and K. Ko, "New perspectives on how to discover drugs from herbal medicines: CAM's outstanding contribution to modern therapeutics," eCAM, pp. 125, 2013.Available at: https://doi.org/10.1155/2013/627375.

[6] A. Karimi, M. Majlesi, and M. Rafieian-Kopaei, "Herbal versus synthetic drugs; beliefs and facts," Journal of Nephropharmacology, vol. 4, pp. 27-30, 2015.

[7] M. Ekor, "The growing use of herbal medicines: Issues relating to adverse reactions and challenges in monitoring safety," Frontiers in Pharmacology, vol. 4, p. 177, 2014.Available at: https://doi.org/10.3389/fphar.2013.00177.

[8] N. Abbaspour, R. Hurrell, and R. Kelishadi, "Review on iron and its importance for human health," Journal of Research in Medical Sciences, vol. 19, pp. 164-174, 2014.

[9] F. Al-Sayes, M. Gari, S. Qusti, N. Bagatian, and A. Abuzenadah, "Prevalence of iron deficiency and iron deficiency anemia among females at university stage," Journal of Medical Laboratory and Diagnosis, vol. 2, pp. 5-1 1, 2011.

[10] National Heart Lung and Blood Institute, IN BRIEF: Your guide to anemia, U.S Department of health and human services. United States of America (U.S.A): National Institute of Health, 2011.

[11] J. F. Dahlerup, M. Eivindson, B. A. Jacobsen, N. M. Jensen, S. P. Jørgensen, S. B. Laursen, M. Rasmussen, and T. Nathan, "Diagnosis and treatment of unexplained anemia with iron deficiency without overt bleeding," Danish Medical Journal, vol. 62, p. P166, 2015.Available at: https://doi.org/10.1016/s0016-5107(04)00794-1.

[12] M. K. Nair and V. Iyengar, "Iron content, bioavailability and factors affecting iron status of Indians," Indian Journal of Medical Sciences, vol. 130, pp. 634-45, 2009. 
[13] WHO/UNICEF/UNU, Iron deficiency anaemia: Assessment, prevention, and control. Geneva Switzerland: World Health Organization, 2001.

[14] M. Fiona, A. Singh, R. Sharma, and M. Agrawal, "Risk assessment of heavy metal toxicity through contaminated vegetables from waste water irrigated area of Varanasi, India," Tropical Ecology, vol. 51, pp. 375-387, 2010.

[15] AOAC, "Official methods of analysis (Williams H. ed.)." vol. 2, 15th ed Washington DC., USA: Association of Official Analytical Chemists, 1990, pp. 910-928.

[16] S. Idris, "Compositional studies of Telfairia occidentalis leaves," American Journal of Chemistry, vol. 1, pp. 56-59, 2011.Available at: https://doi.org/10.5923/j.chemistry.20110102.12.

Views and opinions expressed in this article are the views and opinions of the author(s), Journal of Nutrients shall not be responsible or answerable for any loss, damage or liability etc. caused in relation to/arising out of the use of the content. 